\title{
Do Tigers like Politics?
}

\author{
Aishwarya Maheshwari ${ }^{1}$ and Rajeev Maheshwari ${ }^{2}$ \\ ${ }^{1}$ Banda University of Agriculture and Technology \\ ${ }^{2}$ Affiliation not available
}

September 11, 2020

\section{Do Tigers like Politics?}

Aishwarya Maheshwari ${ }^{1 *}$ and Rajeev Maheshwari ${ }^{2}$

${ }^{1}$ Department of Wildlife Sciences, College of Forestry, Banda University of Agriculture and Technology, Banda-210001, Uttar Pradesh, India (ORCID: 0000-0002-6338-4254).

${ }^{*}$ Corresponding author: aishwaryamaheshwari@icloud.com

${ }^{2}$ Independent Political Analyst, India.

In the geopolitically globalised world, political decisions and anthropogenic activities have a direct influence on the survival of wildlife and their interactions with human $(1,2)$. In such scenario, continuous decline in wildlife has generally been as "non-political" amongst political parties (2, 3 ). In the disastrous deterioration of wildlife, increase in number of a globally threatened flagship species (such as tiger Panthera tigris) appears a rare phenomenon in India (4 ). Moreover, such recovery of a large predator entails with healthier natural ecosystems, as a whole and indicates sensible and timely political decisions.

Wildlife conservation is a global environmental concern and inherently politically complex in most parts of the world $(5,6)$. Political parties are the key actors shaping wildlife policies both at national and international level $(2,7)$. As relation between wildlife and politics has for long been a close one in India $(3,8)$. The pre-historic Hindu mythological beliefs are evident with association of the Gods and Goddesses with different vahanas (animal vehicles) in antiquity and epics such as Ramayana and Mahabharata gave protection to wild species $(8)$. In recent decades, world has come to recognize the central importance of wildlife to humanity in terms of the crucial contribution it makes to the cultural, economic, spiritual and social well-being of communities worldwide $(9)$. For example, recent recognition of India's tiger census in 2018 has earned the Guinness Book of World Records for being the world's largest camera-trap wildlife survey and based on the recent knowledge accumulated over the years, India has over $80 \%$ of world's tiger population (4,10 ). Tiger population in India has remarkably increased over the previous decade, with over $110 \%$ since 2006, systematic all India tiger estimation exercise revealed recent numbers ranging around 2603 to 3346 (4). The knowledge that such nationwide exercises acquire is made available to policy makers so that accountable decisions can be made through integrated approach of the politics, science and society.

The purpose of this article is to assess the relationship between ruling political party and estimated tiger population in India. In particular, we seek to determine if and how tiger numbers vary in terms of the ruling political party in the tigers occupying states in India. In addition, Jhala et al. (2019) stated, "Sustained conservation efforts through continued "political will" have resulted in an increase in tiger numbers", and we attempted to assess ruling parties and tiger population dynamics with this article.

We compiled data on tiger population and the ruling political party in 20 states of the respective year, in which the tiger population report was released. We considered the ruling party, whose Chief Minister is in 
the office, in case of a coalition government is formed. Furthermore, if elections were taken place in the same year when tiger population repot was released, two parties were considered for that particular year. There have been four cycles of all India tiger estimation project since 2006, estimated tiger populations 1411, 1706, 2226 and 2967 in 2006, 2010, 2014 and 2018 respectively. If there are elections or any change of the ruling party government, we credited both the parties in that particular year except the President's rule (as it doesn't belong to any political party).

In 2006, of 20 ruling political parties, the Indian National Congress (INC) was leading with 6.5 tiger occupied states (comprising total tiger population 630) followed by the Bharatiya Janta Party (BJP) (four states with 356 tigers) and the CPI (1.5 states and 33 tigers). Similarly, in 2010 the INC was leading with five tiger occupied states with 424 tigers, closely followed by the BJP ruling 4.5 states with almost doubling the tiger numbers (815) in comparison with the INC ruling states (adding two prominent BJP ruling states Uttarakhand and Karnataka) and the Communist Party of India (CPI) (2 states with 141 tigers). Once again, in 2014, the INC was leading with 6.5 tiger occupied states (1175 tigers), closely followed by the BJP's five ruling states (500.5 tigers). In contrast, in 2018, the BJP taken over with huge victory with 8.5 tiger occupied states (1688.5 tigers) and the INC trailed in three states with 603.5 tigers (Table 1 ).

We acknowledge that our approach has possible short-comings such as selection of the ruling political party for the same year in which the tiger numbers were released, whereas the tiger estimation exercise might have been taken under the political regime of previous another party. This problem is difficult to avoid in assessing party specific political agenda would be focusing on a broad policy dimension. Our results suggest that there is no relationship between major ruling political party and tiger population in any of the 20 states in India. Tiger appears to be apolitical, as this study did not approach identity in any instance. Perhaps our most important implication pertains to the ideological foundation of each apolitical party in periodically monitoring tiger population.

This brief study contributes to the nascent literature on bringing together both tiger numbers and ruling political parties by presenting a new approach that we applied to 20 tiger harbouring states in India. Unlike Western political system, green parties are lacking in India and wildlife has difficulties with getting involved in political discourse. However, India has achieved its target of doubling the tiger count four years ahead of $2022(4)$ which reflects favourable conservation policy and "political will" for tigers in India.

\section{References}

1. J.A. McNeely, M. Gadgil, C. Leveque, C. Padoch, K. Redford (lead authors). 1995. Characterization of biodiversity. In: Heywood, V.H., Watson, R.T., and Baste, I. (eds.). Global biodiversity assessment. Cambridge University Press. Cambridge. Pp. 715-821.

2. T. Hodgetts, D. Burnham, A. Dickman, E. A. Macdonald, D. W. Macdonald. 2019. Conservation Geopolitics. Conservation Biology 33:250-259. doi:10.1111/cobi.13238

3. V. K. Saberwal. 2000. Conservation as politics: Wildlife conservation and resource management in India, Journal of International Wildlife Law \& Policy, 3:166-173. doi: 10.1080/13880290009353954

4. Y. V. Jhala, Q. Qureshi, A. K. Nayak (eds). 2019. Status of tigers, co-predators and prey in India 2018. Summary Report. National Tiger Conservation Authority, Government of India, New Delhi \& Wildlife Institute of India, Dehradun. TR No./2019/05.

5. Jean-Louis Martin, V. Maris, D. S. Simberloff. 2016. Limits challenge society and conservation science. Proceedings of the National Academy of Sciences, 113: 6105-6112, doi:10.1073/pnas.1525003113

6. S. J. Song, R. M. M'Gonigle. 2001. Science, power, and system dynamics: The political economy of conservation biology. Conservation Biology, 15:980-989

7. C. A. Simon, B. S. Steel, N. P. Lovrich. 2018. State and local government and politics: Prospects for sustainability, $2^{\text {nd }}$ edition, Oregon State University Corvallis.

8. M. Rangarajan. 2001. India's wildlife history. Permanent Black and Ranthambore Foundation, New Delhi.

9. Ph. Chardonnet, B.des Clers, J. Fischer, R. Gerhold, F. Jori, F. Lamarque. 2002. The value of wildlife. Scientific and Technical Review of the Office International des Epizooties, 21:15-51. 
10. Millward. 2020. Indian tiger study earns its stripes as one of the world's largest wildlife surveys. https://www.guinnessworldrecords.com/news/2020/7/indian-tiger-study-earns-its-stripes-asone-of-the-world's-largest-wildlife-surve-624966

Table 1. Tiger harbouring states and their numbers during four phases of All India Tiger Monitoring exercise.

\begin{tabular}{|c|c|}
\hline State & Years in which tiger numbers were released and ruling political parties with the tiger nu \\
\hline & 2006 \\
\hline Tamil Nadu & All India Anna Dravida Munnetra Kazhagam (AIADMK) - Dravida Munnetra Kazhagam (DMK) -76 \\
\hline Odisha & Biju Janata Dal (BJD) - 45 \\
\hline Chhattisgarh & BJP - 26 \\
\hline Madhya Pradesh & BJP - 300 \\
\hline Arunachal Pradesh & BJP - 14 \\
\hline Rajasthan & BJP till March 2008 then INC - 32 \\
\hline Jharkhand & BJP till Sept. 2006 then Jharkhand Mukti Morcha (JMM) \\
\hline Bengal & Communist Party of India (CPI Marxist) - 10 \\
\hline Uttarakhand & INC - 178 \\
\hline Andhra Pradesh & INC - 95 \\
\hline Maharashtra & INC - 103 \\
\hline Goa & INC \\
\hline Assam & INC - 70 \\
\hline Kerala & INC - Communist Party of India - 46 \\
\hline Karnataka & INC - Janta Dal (Secular) - 290 \\
\hline Bihar & Janata Dal (United) (JDU) - 10 \\
\hline Mizoram & Mizo National Front - 6 \\
\hline Nagaland & Nagaland People's Front \\
\hline Uttar Pradesh & Samajwadi Party (SP) - 109 \\
\hline Telangana & State was not formed \\
\hline
\end{tabular}

